\title{
EED Gene
}

National Cancer Institute

\section{Source}

National Cancer Institute. EED Gene. NCI Thesaurus. Code C101721.

This gene plays a role in the negative regulation of transcription. 